\title{
Astroprincin (FAM171A1, C10orf38)
}

\section{A Regulator of Human Cell Shape and Invasive Growth}

\author{
Tiina Rasila, ${ }^{*}$ Olga Saavalainen, ${ }^{*}$ Hesham Attalla, ${ }^{*}$ Petri Lankila, ${ }^{*}$ Caj Haglund, ${ }^{\dagger \ddagger}$ Erkki Hölttä, ${ }^{*}$ and Leif C. Andersson* \\ From the Department of Pathology* and the Research Programs Unit, ${ }^{\dagger}$ Translational Cancer Biology, University of Helsinki, Helsinki; and HUSLAB, ${ }^{\ddagger}$ \\ Helsinki University Hospital, Helsinki, Finland
}

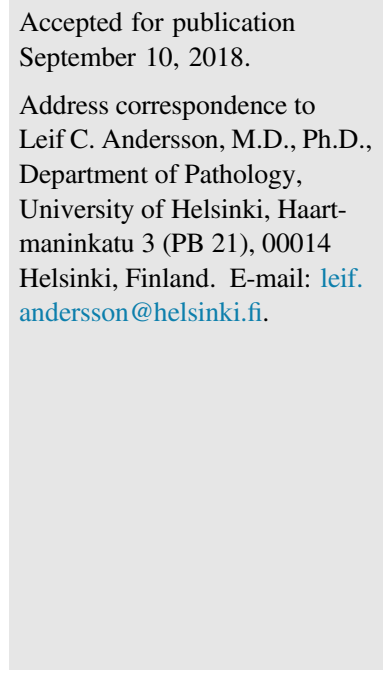

Accepted for publication

September 10, 2018 .

Department of Pathology,

University of Helsinki, Haartmaninkatu 3 (PB 21), 00014

Helsinki, Finland. E-mail: leif. andersson@helsinki.fi.

\begin{abstract}
Our group originally found and cloned cDNA for a 98-kDa type 1 transmembrane glycoprotein of unknown function. Because of its abundant expression in astrocytes, it was called the protein astroprincin (APCN). Two thirds of the evolutionarily conserved protein is intracytoplasmic, whereas the extracellular domain carries two N-glycosidic side chains. APCN is physiologically expressed in placental trophoblasts, skeletal and hearth muscle, and kidney and pancreas. Overexpression of APCN (CDNA) in various cell lines induced sprouting of slender projections, whereas knockdown of $A P C N$ expression by siRNA caused disappearance of actin stress fibers. Immunohistochemical staining of human cancers for endogenous APCN showed elevated expression in invasive tumor cells compared with intratumoral cells. Human melanoma cells (SKMEL-28) transfected with APCN CDNA acquired the ability of invasive growth in semisolid medium (Matrigel) not seen with control cells. A conserved carboxyterminal stretch of 21 amino acids was found to be essential for APCN to induce cell sprouting and invasive growth. Yeast two-hybrid screening revealed several interactive partners, of which ornithine decarboxylase antizyme-1, NEEP21 (NSG1), and ADAM10 were validated by coimmunoprecipitation. This is the first functional description of APCN. These data show that APCN regulates the dynamics of the actin cytoskeletal and, thereby, the cell shape and invasive growth potential of tumor cells. (Am J Pathol 2019, 189: 177-189; https://doi.org/10.1016/ j.ajpath.2018.09.006)
\end{abstract}

We originally obtained evidence for a previously uncharacterized protein, when a human brain expression library was screened with a polyclonal antibody made in sheep against human brain homogenate. The full-length cDNA was cloned and its mRNA was initially deposited on July 11, 2004, in GenBank (https://www.ncbi.nlm.nih.gov/ nuccore; accession number AY683003.1). A peptide antibody to the protein was generated, and a high expression was found in brain astrocytes by immunohistochemistry; hence, the protein was named astroprincin (APCN).

With the clone mapping and sequencing of human chromosome 10, the APCN gene was identified and the coding sequence was annotated as C10orf38, subsequently called FAM171A1. ${ }^{1}$ On the basis of the coding sequence, APCN was found to be a protein of $98-\mathrm{kDa}$ size containing 890 amino acids (https://www.ncbi.nlm.nih.gov; accession number NP_001010924.1).
There is scanty previous information on APCN in the literature. APCN/FAM171A1 has occurred in different settings of screening for gene expression or proteomics. Simmen et $\mathrm{al}^{2}$ investigated the impact of the transcription regulator Krüppel-like factor 9 in human HEC-1-A endometrial carcinoma cells. Among the genes showing enhanced mRNA expression on overexpression of Krüppellike factor 9 was C10orf38, annotated as putative membrane-associated protein. Liao et $\mathrm{al}^{3}$ searched for proteins carrying ZU5 motifs and found the presence of extracellular ZU5-like domains in the FAM171 proteins.

\footnotetext{
Supported by The Academy of Finland grant 265620 (L.C.A.), The Sigrid Jusélius Foundation (L.C.A. and C.H.), The Magnus Ehrnrooth Foundation (L.C.A.), Finska Läkaresällskapet (L.C.A.), and Liv och Hälsa (L.C.A.).

T.R. and O.S. contributed equally to this work.

Disclosures: None declared.
} 
The ZU5 domains are versatile protein-protein interaction modules mediating, for example, bridging between ankyrin and $\beta$-spectrin. ${ }^{4}$

Prunotto et $\mathrm{al}^{5}$ performed proteomic analysis of podocyte exome-enriched fractions from human urine and found FAM171A1 among the 1195 identified proteins. In a study by temporal proteomics during nerve growth factor-induced neural outgrowth in SH-SY5Y neuroblastoma cells, FAM171A1 was among the 1923 proteins showing transiently up-regulated expression. ${ }^{6}$

St-Denis et $\mathrm{al}^{7}$ used complementary affinity purification and proximity-based interaction proteomics to screen for interactomes of 140 human proteins with phosphatase catalytic domains. Among the 1335 identified proteins, FAM171A1 was found to interact with the protein tyrosine phosphatase receptor type $\mathrm{F}$ or leukocyte antigen-related tyrosine phosphatase. ${ }^{7}$ This transmembrane tyrosine phosphatase has been functionally linked to adherent junctions between epithelial cells and involved in regulation of $\beta$-catenin signaling. Huttlin et $\mathrm{al}^{8}$ investigated HEK293T cells by affinity purification-mass spectrometry proteomics and found evidence for interaction between FAM171A1 and procadherin $\gamma$ subfamily B1, a calciumdependent cell adhesion protein that has been implicated in the establishment and maintenance of brain neuronal connections. ${ }^{9}$

In a genome-wide transcriptome analysis of human epidermal melanocytes, Haltaufderhyde and Oancea ${ }^{10}$ found a 12-fold up-regulated expression of FAM171A1 in lightly pigmented melanocytes compared with darkly pigmented cells. Santuario-Facio et al ${ }^{11}$ analyzed genetic signatures of high-grade breast cancer and found FAM171Al among the nine tumor-associated genes displaying overexpressed expression in triple-negative aggressive tumors.

There is, however, no previous information about the molecular function(s) of APCN/FAM171A1. This study reports the first functional characterization of the APCN protein. It shows that APCN is an evolutionarily conserved 98-kDa transmembrane type I glycoprotein expressed in various normal and malignant cells. Data demonstrate that APCN is involved in regulation of the cytoskeletal dynamics and, thereby, the cell shape and invasive growth of tumor cells.

\section{Materials and Methods}

\section{Bioinformatics}

Online databases and tools (ExPASy, https://www.expasy. org, last accessed December 12, 2016; Swiss Institute of Bioinformatics, Lausanne, Switzerland) were used to identify known motifs from the APCN sequence. Onlinealignment services Basic Local Alignment Search Tool (BLAST; http://blast.ncbi.nlm.nih.gov/Blast.cgi, last accessed February 5, 2018), Multiple Alignment using Fast Fourier Transform (MAFFT; https://mafft.cbrc.jp/alignment/server, last accessed October 10, 2017), and ClustalW2 (http://www. ebi.ac.uk/Tools/clustalw2/index.html, last accessed October $10,2017)$ were used to compare APCN sequences between different species.

To determine the tissue transcription profile of $A P C N$, a radioactive probe was prepared for the region, spanning nucleotides 86 to 417 of the open reading frame and hybridized to a Multiple Tissue Expression Array and Multiple Tissue Northern Blot (Clontech Laboratories, Palo Alto, CA), as described previously. ${ }^{12}$

\section{In Situ Hybridization}

Tissue sections from early (sixth week of gestation) placenta were hybridized with antisense and sense complementary RNA probes corresponding to the region 808 to 1237 of APCN cDNA. The complementary RNA probes were labeled with digoxigenin-UTP by in vitro transcription with T7 polymerase using a DIG RNA Labelling Kit (Roche Diagnostics GmbH, Mannheim, Germany), and $200 \mathrm{ng}$ of the probe was used for each hybridization. A Ventana Discovery Staining Platform was used for automated hybridization. Detection of the DIG label was performed with monoclonal biotinylated anti-digoxin antibody (Jackson Immuno Research Laboratories Inc., West Grove, PA) at 1:2000 dilution using a BlueMap kit (Ventana Medical Systems Inc., Tucson, AZ). The slides were counterstained with Nucleofast Red (Ventana Medical Systems Inc.).

\section{Preparation of Peptide Antibodies to APCN in Rabbits}

A synthetic peptide (SVTSHGRPEAPGTKELM) corresponding to amino acids 378 to 394 of APCN was synthesized on a four-branch lysine core as multiple antigen presentation peptide $\left(\mathrm{MAP}_{4}\right)$ with Applied Biosystems (Foster City, CA) 433A automated peptide synthesizer using Fmoc chemistry. The peptide was purified by reverse-phase high-performance liquid chromatography and verified by matrix-assisted laser adsorption time-of-flight spectroscopy.

Two female rabbits were immunized with $400 \mu \mathrm{g}$ of the peptide polymer in Freund's complete adjuvant. After 4 weeks, three booster injections with $200 \mu \mathrm{g}$ peptide polymer in Freud's incomplete adjuvant were given with 3 -week intervals; and 10 days after the last immunization, blood was collected and the sera were isolated. The antibody was produced at the Viikki Laboratory Animal Center, University of Helsinki (Helsinki, Finland). All animals were handled in strict accordance with good animal practice, as defined by the relevant Finnish animal welfare bodies, and the European Communities Council directive (86/609/EEC).

\section{Immunostaining}

Formalin-fixed, paraffin-embedded anonymous tissue specimens were collected from the archives of the HUSLAB and 
the Department of Pathology, Haartman Institute, University of Helsinki, in accordance with the Finnish legislation and local ethical guidelines. Sections ( $4 \mu \mathrm{m}$ thick) were deparaffinized in xylene and rehydrated. Antigen was retrieved by microwaving in $10 \mathrm{mmol} / \mathrm{L}$ citric acid monohydrate for $3 \times 5$ minutes at $650 \mathrm{~W}$. Endogenous peroxidase activity was blocked by treatment with $0.5 \% \mathrm{H}_{2} \mathrm{O}_{2}$. The slides were incubated overnight in a refrigerator at $4{ }^{\circ} \mathrm{C}$ with the primary antibody in phosphate-buffered saline (PBS) containing $0.5 \%$ normal human serum. The same procedure was used for negative controls, except that the incubation overnight took place in PBS diluent without antibody. The reaction was visualized with 3-amino-9-ethylcarbazole (Vectastain; Vector Laboratories, Burlingame, CA). Immunohistochemical staining of some sections was performed in an Autostainer 480 (Lab Vision Corp., Fremont, CA) by the Dako REAL EnVision Detection System, Peroxidase/ DAB +, Rabbit/Mouse (Dako, Glostrup, Denmark).

Cells grown on coverslips were rinsed once with cold PBS and fixed in ice-cold methanol for 10 minutes at $4{ }^{\circ} \mathrm{C}$. Alternatively, cells were fixed with $3.5 \%$ paraformaldehyde for 15 minutes at room temperature and permeabilized with 0.02\% IGEPAL CO-630 (Sigma Aldrich, St. Louis, MO) for 20 minutes at room temperature. Blocking was done with human serum diluted 1:10 in 1× PBS or with Background Blocker (Enzo Life Sciences, Farmingdale, NY) for $30 \mathrm{mi}-$ nutes at room temperature. Cells were first incubated with primary antibody for 1 hour, washed three times with $1 \times$ PBS, and then incubated with species-appropriate secondary antibodies conjugated with either Alexa Fluor-488 or Alexa Fluor-555 (both at 1:1000 dilution; Thermo Fisher Scientific, Waltham, MA) or with fluorescein isothiocyanate goat anti-mouse (at 1:50 dilution; Dako) or tetramethylrhodamine (TRITC) swine anti-rabbit (at 1:30 dilution; Dako).

Wheat germ agglutinin-TRITC $(20 \mu \mathrm{g} / \mathrm{mL}$; EY Laboratories Inc., San Mateo, CA) was used to visualize cell surface membrane. Wheat germ agglutinin-TRITC was added to cells grown on coverslips after initial rinsing, incubated for 30 minutes at $4^{\circ} \mathrm{C}$ in the dark, and fixed.

\section{Cell Cultures and Transient Transfections}

COS-7, HEK293, MCF-7, NIH3T3, and SK-MEL-28 cell lines were obtained from ATCC (Manassas, VA). The U373MG astrocytoma line was kindly provided by Prof. Bengt Westermark (University of Uppsala, Uppsala, Sweden), and SK-MEL-103 (NRAS Q61R) and SK-MEL147 (NRAS Q61R) both originated from Dr. Alan Houghton (Memorial Sloan-Kettering Cancer Center, New York, NY) and were kindly provided by Dr. Maria Soengas (Spanish National Cancer Research Center, Madrid, Spain). The cell lines, except for COS-7, were grown in RPMI 1640 medium supplemented with $10 \%$ (v/v) fetal bovine serum (Sigma-Aldrich), $1 \mathrm{mmol} / \mathrm{L}$ L-glutamine, 50 $\mathrm{mg} / \mathrm{mL}$ penicillin, and $50 \mathrm{mg} / \mathrm{mL}$ streptomycin at $37^{\circ} \mathrm{C}$ in a humidified atmosphere of $5 \% \mathrm{CO}_{2}$ in air. COS-7 cells were grown under similar conditions in Dulbecco's modified Eagle's medium.

Cells were transfected using Lipofectamine 2000 transfection reagent (Invitrogen, Carlsbad, CA) or with FuGENE6 transfection reagent (Roche Diagnostics $\mathrm{GmbH}$ ), according to the manufacturer's directions. Lipofectamine was also used when cells were transfected with 6-carboxyfluorescein-labelled siRNA against FAM171A1 (Sigma-Aldrich) and control siRNA (Ambion; Thermo Fisher Scientific). Lines of SK-MEL-28 cells stability overexpressing APCN or pcDNA3 empty vector were selected by cultivation in the presence of $1000 \mu \mathrm{g} / \mathrm{mL}$ G418.

\section{RNA Interference}

SK-MEL-147 and U373MG cells were seeded on coverslips $(18 \mathrm{~mm})$ at 30,000 cells per well on a 12-well scale or 100,000 cells per 6 -well scale 24 hours before siRNA transfection. Cells were transfected with $20 \mathrm{nmol} / \mathrm{L}$ APCN siRNA 6-FAM (sense, 5'-CUGAUGAGUGGAGUCCAUU [dT][dT][6FAM]-3'; antisense, 5'-AAUGGACUCCACUCAUCAG-3') or $20 \mathrm{nmol} / \mathrm{L}$ MISSION siRNA Fluorescent Universal Negative Control Number 1, 6-FAM (SigmaAldrich). Cells were transfected using MISSION siRNA Transfection Reagent (Sigma-Aldrich), according to manufacturer's protocol.

\section{RT-PCR, Real-Time Quantitative PCR, and Primers}

To examine the transcription of the APCN gene in cells, total RNA was extracted using the TRI REAGENT-RNA/ DNA/Protein isolation reagent (Molecular Research Center, Inc., Cincinnati, $\mathrm{OH}$ ), according to the manufacturer's instructions. Total RNA $(1 \mu \mathrm{g})$ was reverse transcribed with the High Capacity RNA-to-cDNA Kit (Applied Biosystems, Foster City, CA), and cDNA was used as a template for quantitative real-time PCR analysis using a Maxima SYBR Green/ROX qPCR Master Mix (Thermo Fisher Scientific) and a LightCycler II instrument (Roche Diagnostics $\mathrm{GmbH}$ ). Primers used for real-time analysis included the following: APCN, 5'-TTACCACGTATCACACGGTG-3' (forward) and 5'-TTTGGAACTCTCCAGTCCTG$3^{\prime}$ (reverse); and glyceraldehyde-3-phosphate dehydrogenase, 5'-GGTGAAGGTCGGAGTCAAC-3' (forward) and 5'-CAAATGAGCCCCAGCCTTC-3' (reverse).

\section{Antibodies}

The following antibodies were used in this study (including dilutions/amounts used for immunofluorescence, immunohistochemistry, Western blot analysis, or immunoprecipitation): MAP346 (1:70, immunofluorescence; 1:400, immunohistochemistry; 1:200, Western blot analysis), FLAG (F3165; Sigma-Aldrich; $10 \mu \mathrm{g} / \mathrm{mL}$, immunofluorescence; $3 \mu \mathrm{g} / \mathrm{mL}$, Western blot analysis; 5 or $7.5 \mu \mathrm{g}$, 
immunoprecipitation), Myc (562; MBL International, Woburn, MA; 1:3000, Western blot analysis; and M4439; Sigma-Aldrich; 1:7000 Western blot analysis, $7.5 \mu \mathrm{g}$ immunoprecipitation), NSG1 (HPA035775; Sigma-Aldrich; 1:100 Western blot analysis; and bs-840R; Bioss Antibodies, Woburn, MA), green fluorescent protein (632375; Clontech Laboratories, Mountain View, CA; $3 \mu \mathrm{g} / \mathrm{mL}$ immunofluorescence), ADAM10 (MAB1427; R\&D Systems; 1:50 immunohistochemistry; and sc-48400; Santa Cruz Biotechnology, Dallas, TX; 1:20 immunofluorescence), and antizyme-1 (AZ-1; HPA009291; SigmaAldrich; 1:2000 Western blot analysis).

\section{Imaging}

Microphotographs were taken with an Olympus BX51 microscope (Olympus Corp., Shinjuku, Japan) equipped with a Nikon Digital Sight DS-U1 camera system (Nikon
Corp., Shinjuku, Japan), a Zeiss Axioplan 2 Imaging fluorescence microscope (Carl Zeiss AG, Oberkoschen, Germany), and a Leica confocal laser-scanning microscope (Leica TCS SP2; Leica Microsystem GmbH, Wetzlar, Germany).

\section{Yeast Two-Hybrid Screening}

Yeast two-hybrid screening was performed using the Matchmaker GAL4 Two-Hybrid System 3 (Clontech Laboratories, Palo Alto, CA). The full-length APCN cDNA was cloned in frame with the GAL4 DNA-binding domain of pGBKT7 vector and then used as a bait construct. The bait construct was then transformed into yeast strain AH109. The yeast strain Y187 was pretransformed with a human placenta Matchmaker cDNA library (Clontech Laboratories, Palo Alto, CA) in the pACT2 vector.

Table 1 The List of Oligonucleotides Used in This Study

\begin{tabular}{|c|c|c|}
\hline Application & Name & Sequence \\
\hline \multirow[t]{2}{*}{ fLAPCN } & flAPCN-For & $5^{\prime}$-AAAAAGCTTATGAGCAGGTCCGCGACGCTGCTGC- $3^{\prime}$ \\
\hline & flAPCN-Rev & 5'-AAAGGATCCTTTAATGTTAAACGCCATCAGG-3' \\
\hline & flAPCN-Rev & 5'-AAAGGATCCTTTAATGTTAAACGCCATCAGG-3' \\
\hline \multirow[t]{2}{*}{ tcAPCN } & tcAPCN-For & 5'-TAAAAGCTTATGCACACGGTGTTTCTTTTGG-3' \\
\hline & flAPCN-Rev & 5'-AAAGGATCCTTTAATGTTAAACGCCATCAGG-3' \\
\hline \multirow[t]{2}{*}{ T1-APCN } & flAPCN-For & 5'-AAAAAGCTTATGAGCAGGTCCGCGACGCTGCTGC-3' \\
\hline & T1-APCN-Rev & 5'-AAAGGATCCGAGAGACTCCGACATGGATGCGTTCTGAGG- 3' \\
\hline \multirow[t]{2}{*}{ T2-APCN } & T2-APCN-For & 5'-AAAAAGCTTATGCCTGAGAACACCAGCTACAGTGACC-3' \\
\hline & flAPCN-Rev & 5'-AAAGGATCCTTTAATGTTAAACGCCATCAGG-3' \\
\hline T3-APCN & flAPCN-For & 5'-AAAAAGCTTATGAGCAGGTCCGCGACGCTGCTGC- $3^{\prime}$ \\
\hline$\triangle 1-A P C N$ & flAPCN-Rev & 5'-AAAGGATCCTTTAATGTTAAACGCCATCAGG-3' \\
\hline \multirow[t]{4}{*}{$\triangle 3-A P C N$} & flAPCN-For & 5'-AAAAAGCTTATGAGCAGGTCCGCGACGCTGCTGC-3' \\
\hline & $\triangle 3-A P C N-R e v$ & 5'-CCGGGCTGATTTTGGTTCATTCATCATACATTCAGTGGGTCTG-3' \\
\hline & $\triangle 3-A P C N-F o r$ & $5^{\prime}-\mathrm{AATGAACCAAAATCAGCCCGG-3^{ \prime }}$ \\
\hline & flAPCN-Rev & 5'-AAAGGATCCTTTAATGTTAAACGCCATCAGG-3' \\
\hline \multirow[t]{2}{*}{$A P C N_{\mathrm{S} 136 \mathrm{~A}}$} & S136A_APCN_for & 5'-CGTCCAAATAGTAGCAGGATTCCAAGGTGCC-3' \\
\hline & S136A_APCN_rev & 5'-GGCACCTTGGAATCCTGCTACTATTTGGACG-3' \\
\hline \multirow[t]{2}{*}{$A P C N_{\mathrm{N} 159 \mathrm{~A}}$} & N159A_APCN_for & $5^{\prime}$-CTGAGGTTGCCTGAGGCCACCAGCTACAGTGAC-3' \\
\hline & N159A_APCN_rev & 5'-GTCACTGTAGCTGGTGGCCTCAGGCAACCTCGA-3' \\
\hline \multirow[t]{2}{*}{$A P C N_{\mathrm{N} 190 \mathrm{~A}}$} & N190A_APCN_for & $5^{\prime}$-GGATTAGACGGAGCTGGAACAGGAAACAGC-3' \\
\hline & N190A_APCN_rev & 5'-GCTGTTTCCTGTTCCAGCTCCGTCTAATCC-3' \\
\hline
\end{tabular}




\section{cDNA Constructs}

The full-length Astroprincin-cDNA (fl $A P C N$, amino acids 1 to 890) from ZM6-a10 C10orf38 Image Clone (Geneservice, Cambridge, UK) was cloned into CMV14-vector (Sigma-Aldrich) containing 3xFLAG-tag with PCR oligonucleotides (all PCR oligonucleotides were purchased from Oligomer, Helsinki, Finland) using HindIII and BamHI sites. The oligonucleotides are described in Table 1. Standard DNA techniques were applied, as described. ${ }^{13}$ Different $\mathrm{N}$ - and C-terminally truncated (cDNA) APCN constructs (Supplemental Figure S1) were amplified from a fl $A P C N$-CMV14 construct using specific primers that introduced HindIII and BamHI sites, followed by cloning into CMV14.

Internal deletion variants of (cDNA) $A P C N$ were constructed with two-step overlap extension PCR. ${ }^{14}$ First, two PCR products representing flanking regions of the $A P C N$ sequence to be deleted were prepared by using one nonchimeric and one chimeric primer (Table 1). Second, two PCR products were used as template for a ligation PCR, with the outmost primer pair containing HindIII and BamHI sites.

Four point mutations (S136A, N159A, N190A, and N194A) in the extracellular portion were made, as described by Edelheit et al. ${ }^{15}$ In brief, the point mutation is generated with a reverse-complementary primer-pair containing the wanted mutation. Using flAPCN in a CMV14-plasmid as a template, two PCRs were performed with only one primer in each and the two PCR products were mixed, denatured, and randomly reannealed. The methylated template strands were digested with DpnI, leaving only the pairs with fresh PCRstrand intact. The DpnI reaction was subsequently stopped by heat inactivation $\left(20\right.$ minutes at $\left.80^{\circ} \mathrm{C}\right)$. The double-point mutant N159A/N194A was similarly made by using N194A_APCN-FLAG as template and N159A as mutation primer. flAPCN was also cloned in the pEGFP-N1-vector (Clontech Laboratories) to produce APCN-enhanced green fluorescent protein fusion protein.

For construction of Flag-NEEP21, the corresponding DNA fragments were amplified from Human Universal QUICK-Clone cDNA (Clontech Laboratories) using specific primers (Table 1), introducing HindIII and BamHI sites, and cloned into CMV14 (Sigma-Aldrich). The MycNEEP21 expression construct was generated by amplification of Neep21 from Flag-Neep21 expression vector using specific primers that introduce EcoRI and SalI sites (Table 1), followed by cloning into pAMC. pCI-Neo (Promega, Madison, WI) containing N-terminal c-Myc ${ }^{16}$ was a gift from Dr. Tomi Mäkelä (University of Helsinki). All constructs were verified by sequencing.

Ornithine decarboxylase AZ-1 cDNA was kindly provided by Prof. Shin-ichi Hayashi (Jikei University School of Medicine, Tokyo, Japan). The Myc-ADAM10 expression construct (Addgene, Watertown, MA; plasmid number $31717)^{17}$ was a gift from Dr. Rik Derynck (Department of
Cell and Tissue Biology, University of California, San Francisco, San Francisco, CA).

\section{Cell Invasion Assay}

To investigate invasive cell growth, spheroids of cells were generated by cultivation overnight on agarose-coated trays or on bacterial plates. Spheroids were manually collected and transferred to 96-well tissue trays precoated with Matrigel (BD Biosciences, San Jose, CA) and overlaid with a second layer of Matrigel.

\section{Immunoprecipitation}

COS-7 cells were transfected, collected after 24 hours in PBS, and lysed in lysis buffer $(50 \mathrm{mmol} / \mathrm{L}$ Tris- $\mathrm{HCl}, \mathrm{pH} 7.5$, $150 \mathrm{mmol} / \mathrm{L} \mathrm{NaCl}, 1 \%$ Nonidet $\mathrm{P} 40,0.5 \%$ sodium deoxycholate, and protease inhibitor cocktail; Roche Diagnostics $\mathrm{GmbH}$ ). For preclearing, protein-G-agarose beads (Roche Diagnostics $\mathrm{GmbH}$ ) were added to cleared cell lysates for 1 hour at $4^{\circ} \mathrm{C}$. Supernatants were subjected to immunoprecipitation using the indicated antibodies ( 5 to $7.5 \mu \mathrm{g}$ ) for 3 hours at $4^{\circ} \mathrm{C}$, and protein-G-agarose beads were added overnight for immunoprecipitation. The beads were washed and suspended into $2 \times$ Laemmli sample buffer. Samples were separated on SDS-PAGE and analyzed by Western blot analysis.

\section{SDS-PAGE and Western Blot Analysis}

For immunoblot analysis, the cells were sonicated in $2 \times$ Laemmli sample buffer and heated to $100^{\circ} \mathrm{C}$ for 5 minutes. The amount of proteins present in total cell lysates was quantified by the Bradford assay (Bio-Rad, Hercules, CA). Proteins were resolved by $10 \%$ or $12 \%$ SDS-PAGE and transferred to hydrophobic Immobilon polyvinylidene difluoride membranes (Millipore, Burlington, MA). The membranes were blocked with Odyssey blocking buffer (LICOR Biosciences, Lincoln, NE) and incubated with primary antibodies, followed by Alexa Fluor-680 goat anti-rabbit (Thermo Fisher Scientific) and IRDye 800CW donkey antimouse (LI-COR Biosciences) antibodies (both diluted 1:10,000). An Odyssey Infrared Imager (LI-COR Biosciences) was used for visualization.

\section{Results}

\section{Cloning and Sequence}

Human APCN is a $98-\mathrm{kDa}$ protein consisting of 890 amino acids. The coding gene is located on chromosome 10p13. The $A P C N$ sequence is also annotated FAM171A1 or C10orf38.

In silico database search shows that APCN has no homology to previously functionally characterized human proteins. APCN is evolutionarily highly conserved. The homologous Fam171a1 protein of mouse (https://www.ncbi.nlm.nih.gov; 
Homo sapiens Mus musculus Gallus gallus Xenopus laevis Danio rerio

Homo
Mus
Gallus
Xenopus
Danio

Homo
Mus

Mus
Gallus

Xenopus

Danio

Homo
Mus

Mus
Gallus

Xenopus

Danio

Homo

Mus

Gallus

Xenopus

Danio

Homo

Mus
Gallus

Xenopus

Xenopus

Homo

Mus
Gallus

Xenopus

Danio

Homo

Mus

Gallus

Xenopus

Danio

MS------RSATLLLCLLGCHVWKAVTKT--LREPGAGAQEVTLKVHISDASTHQPVADALIEIFTNQASIASGTSGTDGVAFIKFQYKLGSQLIVTASKHAYVPNSAPWKPIRLPVESS 112 MS-----KSAALLLCLLGCHVWKAVTKT--LQEPGAGAQEVTLKVHISDASTHQPIADALIEIFASQVSVASGTSGTDGVAFIKFPYKLGNQLIVTATKQAYVPNSAPWKPIRLPVFSS 112 MS------RSAALLLCLIGCNVWKAVTKT--LGAP-EAAQEVTLKVHVSDASTHQPVTEAFIEIFTNQISIASGTSGADGTAFLKEQYKLGNQLIVTASKHAYVPNSAPWKPVRLPVESS 111 MSGS----TAVALLFCVLSCSVWGAGSKASHEHNAAAAAQDVTLKVQVSDVSTHQPIADAVIEIFANQVSAASGTTGADGTALVKLQYKLGSQLIVTATKQAYVPNSAPWRPLRLPVESS 116 MRGADRSRRSAVIVLCLLGCALWTTTAKT---LQESSDAKEVVLKVHLSDSSTHQPLSGVTVEVFTNHTPVSSDVSGADGNAFIREPYRLVDLLVVTATKRGYVPNSVPWRPSRLPVESS 117 MRGADRSRRAVIVLCLLGCALWTTTAKT---LQESSDAKEVVLKVHLSDSSTHQPLSGVTVEVFTNHTPVSSDVSGADGNAFIREPYRLVDLLVVTATKRGYVPNSVPWRPSRLPVESS
\[ ::^{*}::^{*}::^{*}::^{*}::^{*}::^{*} \]

LSLGLLPERSATLMVYEDVVQIVSGFQGARPQPRVHFQRRALRLPENTSYSDLTAFLTAASSPSEVDSFPYLRGLDGNGTGNSTRHDLTPVTAVSVHLLSSNGTPVLVDGPIYVTVPLAT 232 LSLGLLPERSATLMVYEDVVQIVSGFQGARPQPRVHFQRRALRLPENTSYSDLTAFLTAASSPSEVDSFPYLRGLDGNGTGNSTRHDLTPVTAVSVHLLSSNGTPVLVDGPIYVTVPLAT 232 LSLGLLPERSATLMVYDDVVQIVSGFQGARTQPQVHFQRRSVKLPENTSYSDLTAYLTAASSPWEVDSFPYLQGLDGNGTGNSTRYDLTPVAAVSVHLLNSDGTPVPVNGPIYVTVPLPT 231 LSLGLLPERSATLMVYDDIVQIVSGFQGSRLQPRVHFQRRALNLPGNATYKDLAAFLTAASTPWEIDSFPYLQGSDGNSTGNNSRFDLTPVTAVSFHLLNSDGTDIPVNGPIYVTVPLPT 236 ISLDLIPERAATIMVYEDVVEIVSGFQGPKIQPRVQFQRRATSI

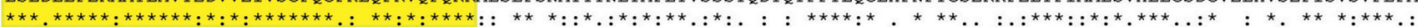

QSSLRHNAYVAAWRFDQKLGTWLKSGLGLVHQEGSQLTWTYIAPQLGYWVAAMSPPIPGPVVTQDITTYHTVFLLAILGGMAFILLVLLCLLLYYCRRKCLKPRQHHRKLQLPAGLESSK 352 QSSLRHNAYVAAWRFDQKLGTWLKSGLGLVHQEGSQLTWTYIAPQLGYWVAAMSPPI PGPVMTQDITTYHTVFLLAILGGMAFILLVLLCLLLYYCRRKCLKPRQHHRKLQLPPALESSK 352 NSNLKHNAHI PAWRFDQKEGTWLKSSLGLVQQEGNQLTWTYIAPQLGYWVAMSPTIPGPVVTHDITSYHTMFLLAILGGMALILLVLLCLLLYYCRRKCLRPRQHHKKLQLPTALDTSK 351 HSSLKHNAHVPAWRFDQKHGTWLKSSIGIIQQEGSQLTWTYIAPQMGYWVAMSPSHPDPVVTQDITSYHTIFLLAILGGIAFILLVLLCILLYYCRRKCLKPRQHHRKLQLSTALDCSK 356 NSGLKENDHIPAWRFDPKLGAWLKSSLGYVQREGKQLTLTYIAPQLGYWAAMSPINTGPVVAKDISTYHTVFLLVILGGMALILLFLLCLLLYYCRRKCTRLRPAHRKFTLSSALDGSK 357

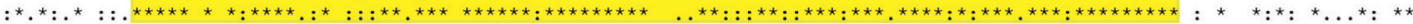

RDOSTSMSHINLLFSRRASEFPGPLSVTSHGRPEAPGTKELMSGVHLEMMSPGGEGDLHTPMLKLSYSTSOEFSSREELLSCKEEDKSOISFDNLTPSGTLGKDYHKSVEVFPLKARKSM 472 RDOATSMSHINLLFSRRASDY PGPLSVSSHSRPEAPGTKELMGGVHLEMMSPKGEGDLHTPMLKLSYSTSOEFSSREELLSHKEEDKSOTSFDNLTPSGTLGKDYHKSVEIFPLKARKSM 472 KDOATSMSHINLIFSRRESEFPGGLSVASNGHTENSGAKELISAVHMEMVSPSGEADMHTPMLKHSFSTSOEFSSREELLSDKEKDKSRISLDDLTPSGSLRKDYHKSADSFPLKTRKST 471 KDQATSMSHIN--------LISPI HMEMLSSSGEADMHT PMLKPSYNTSRDFGSREELISHQEE-KSRMSLDNLTPSGTLRQVYNKSLDHILMKSRKSA 446

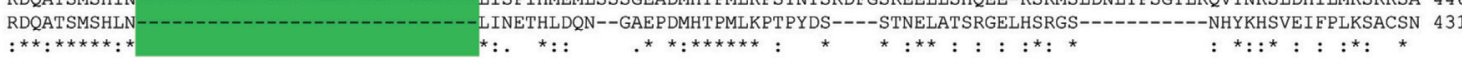

E-REGYESSG-NDDYRGSYNTVLS---QPLFEKQDREG-------PAST-----GSKLTIQEH-LYPAPSS-----PEKEQLIDRRPTECMMSRSVDHLERPTSFPRPGQLICCSSVDQVN 570 E-KEDYEAPG-NDDYRGSYNTVLS---QSLFEKQDQEG------LASA-----GSKLTIQEH-MYHVPLS-----PEKEQLLDRRPTECMMSRSVDHLERPTSFPRPGQLICCSSVDQVN 570

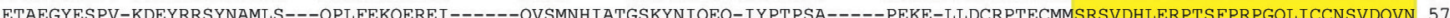
作

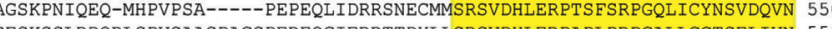

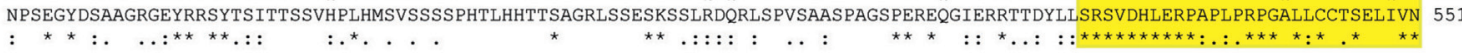

--DSVYRKVLPALVI PAHYMKLPGDHSYVSQPLVVPADQQLEIERLQAELSNPHAGIFPHPSSQIQPQPLSSQAISQQHLQDAGTREWSPQNASMSESLSIPASLNDA--ALAQMNSEVQ 686 --DSVYRKVLPALVIPAHYMKLPGDHSYVSQPLVVPADQQLEIGRLQAELSNPHAGIFPHPSSQIQGQPLSSQAISQQHLQEAGAREWSSQSASMSESLSIPASLNDA--ALAQMNSEVQ 68 6 --DSVYRKVLPALVIPGHYMKLP-EHSEVSQPLVVPADQPIDLERLQAELPNPHARLFPHPPQQLQPQQLTSQAISQQHLQDAGAAEWSQQNASMSESISIPASLNDA--SLAQMNSEVQ 689 --DSVYRNVLPTLVI PAHYVKLPGEHPFVSOOLIVSAEOOFEIERLOAELS---------HAOOMOPPPLSAOAISQQHLQDGEGVEWSTQNAMMSESVSI PASLNDA--AIAOMNGEVO 657

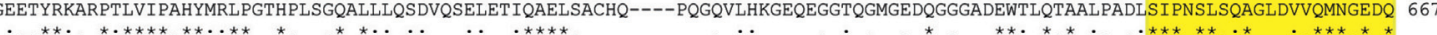

LLTEKALMELGGGKPLPHPRAWFVSLDGRSNAHVRHSYIDLQRAGRN----GSNDASLDSGVDMNEPKSARKGRGDALSLQQN---YPPVQEHQQK-EPRAPDSTAYTQLVYLDD--VEQ 79 LLTEKALMELGGGKPLPHPRAWFVSLDGRSNAHVRHSYIDLQRAGRN----GSNDASLDSGVDMNEPKSARKGRGDPLSLQQS---HTPLQEHQQK-DPRAPDSTACTQLLYLED--MDP 796 LLTEKALMELGGGKPLPHPRAWFVSLDGRSNAHVRHSYIDLQRAGRN----GSNDASLDSGVDMNEPKSARKGRGDHLSTPQS---HPPVQEHQQR-ERKVSDSTAYTQLVYLDD--MDQ 799 LLTEKALMELGGGRPMPHPRAWFVSLDGRSNAHIRHSYIDLQRAGKN----GSNDASLDSGVDMNEPKLGRKLRGEKLSMLHSSMQHPTLQEHQQLNQVNVSDSTAYTQLVYLED--MDQ 771 LLAEKTLMELRGGKPLPHPRAWFVSLDGRSNAHIRHSYIDLQRAGCNSSCVGSNDASLDSGVDMSDVTPGRRVRDKVVVKTEP----------EAQP----AAPVVGHTPVLIVEDSNADE 774

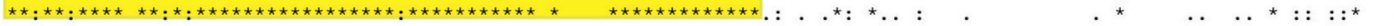

SGSECGTTVCTPEDSALRCLIEGSSRRSGGQ---------------LPSLQEETTRRTADAPSEPAASPHQRRSAHEEEEDDD----DDD--OGEDKKSPWQKREERPLMAFNIK 890 SGSECAATVCTPEDSALRCLIGGSGRSGGQ------------LPSLOETTKRTSDVPI EPIASPNORRSANDEDEDDD----DDDDDQGEDKKSPWOKREERPLMAFNIK 892

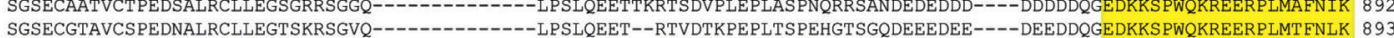

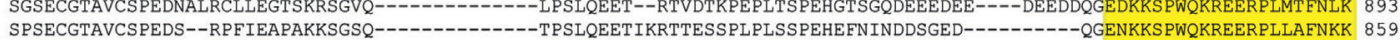
ENSGSPTPVCSPEESALKGLIQEKQSEEDDEGTLSPPSPPPEIPSPPPLPEPVVETSEDTGIDGEVFRTEETPVHMNSSRPDKLLVPDDGGEDENKKSPWQKREERPLLAFNLK 888

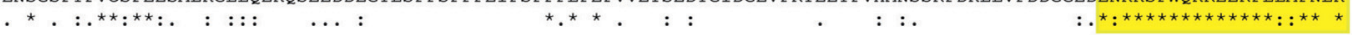

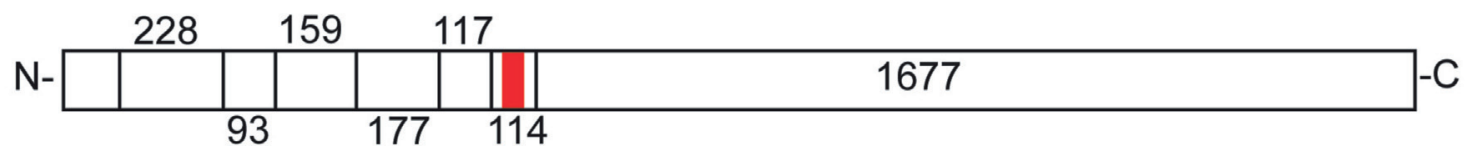

Figure 1 Top panels: Alignment of APCN protein sequences in human (Homo sapiens), mouse (Mus musculus), chicken (Gallus gallus), African clawed frog (Xenopus laevis), and zebra fish (Danio rerio). Conserved regions are marked in yellow. The transmembrane region is marked in red. Sequence missing in aquatic species (amphibian and fish) is marked in green. Bottom panel: Organization and nucleotide lengths of the APCN exons. The transmembrane region (red) is encoded by exon 7, and the intracellular portion is encoded almost exclusively by exon 8. C, carboxyterminal end of the protein; $\mathrm{N}$, amino terminal end of the protein.

accession number NP_001074630) shows 92\% of chicken (accession number XP_418631) 81\% of frog (https://www. ncbi.nlm.nih.gov/protein/NP_001088656; accession number NP_001088656) and 67\% of zebra fish (accession number XP_001335931); 48\% identifies with several large conserved regions in common with human APCN (Figure 1).

\section{The Molecular Structure of APCN}

Different online tools (ExPASy website) were used to predict the APCN protein structure. These suggested that APCN is a type I transmembrane protein with the hydrophobic amino acids from 304 to 324 in the transmembrane region. The orientation of APCN was confirmed by expression of an APCN-green fluorescent protein cDNA construct in COS-7 cells that revealed intracellular localization of green fluorescent protein-labeled C-terminus (Supplemental Figure S2, A-F). The extracellular part of APCN is encoded by the seven short exons and contains several evolutionarily conserved stretches. The region immediately outside and inside the transmembrane stretch, encoded by exon 7 , is virtually identical from zebra fish to human, suggesting some important function. The long intracytoplasmic portion, representing approximately two 

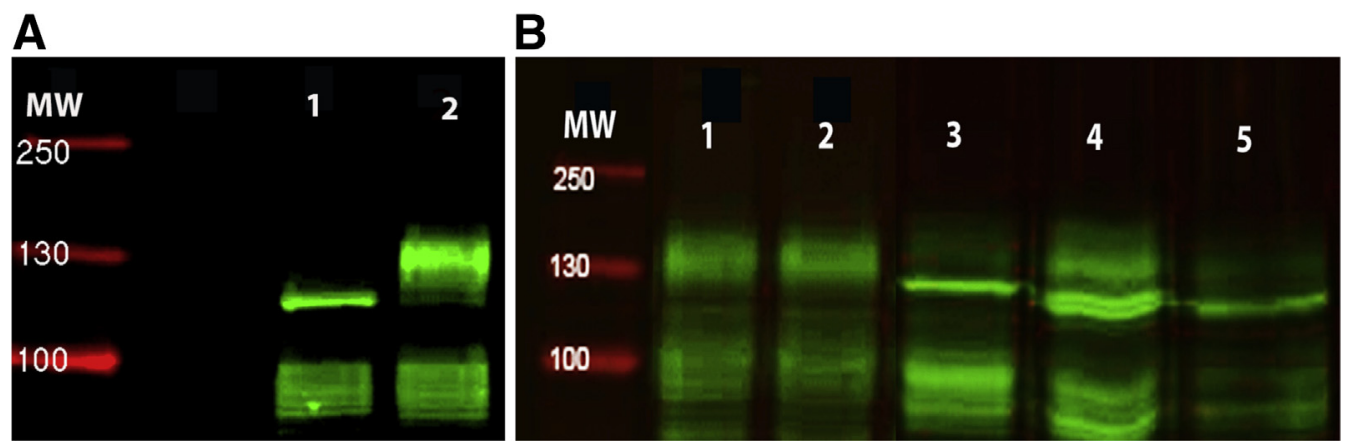

Figure 2 APCN is N-glycosylated. A: Western blot analysis with antibodies to FLAG of lysates from COS-7 cells transfected with (CDNA) flAPCN-Flag and cultured with (lane 1) and without (lane 2) tunicamycin. B: Point mutations showing that N159 and N194 are the major glycosylation sites. Western blot analysis of lysates from COS-7 cells transfected with the following CDNA constructs: fLAPCN-Flag (lane 1), APCN-Flag with mutation of the putative glycosaminoglycan-binding site (VSGF; lane 2), APCN-Flag mutated at N159A (lane 3), APCN-Flag mutated at N194A (lane 4), and double-mutated N159A/ N194A APCN-Flag (lane 5). MW, molecular weight.

thirds of the protein, is encoded almost exclusively by the large exon 8 and contains several evolutionarily conserved regions (Figure 1).

A database search revealed a putative glycosaminoglycanbinding site (VSGF) and three potential N-glycosylation sites (N159, N190, and N194) in the extracellular portion as well as several putative phosphorylation sites throughout the sequence.

\section{APCN Is Glycosylated}

The size of the APCN apoprotein is $98 \mathrm{kDa}$. Western blot analysis with antibodies to FLAG of lysates from COS-7 and MCF-7 cells transfected with (cDNA) APCN-flag revealed a major, slightly diffuse band of $130 \mathrm{kDa}$ apparent molecular weight (MW). Western blot analysis of lysates from transfected cells treated with tunicamycin yielded a band of approximately 100 to $115 \mathrm{kDa}$ (Figure 2A). This reduction in apparent MW is indicative of $\mathrm{N}$-linked glycosylation. The experiment was performed in MCF-7 and COS-7 cells (data not shown), with identical results in both cell lines.

To map the glycosylation pattern, the three predicted $\mathrm{N}$-glycosylation sites were subjected to N-A point mutations (N159A, N190A, and N194A). N190A_APCN gave a Western blot analysis result identical to intact flAPCN. N159A_APCN and N194_APCN yielded reduced expression of the higher MW band with accentuation of the 100- to 115-kDa band. A double-mutant N159/194A-APCN lead to disappearance of the high MW band (Figure 2B). Mutation of the putative glycosaminoglycan binding site (S136A) did not change the apparent MW of APCN (Figure 2B). These findings indicated that N159 and N194 are the N-glycosylation sites. The glycan structures of the $\mathrm{N}$-glycoside side chains remain to be determined.

\section{Tissue Expression of APCN}

A radiolabeled fragment of the cDNA, corresponding to 86 to $417 \mathrm{bp}$ of the coding region, was used as a probe to investigate the tissue distribution of $A P C N$ mRNA. Dot blot analysis revealed expression in various tissues (Supplemental Figure S3A and Supplemental Table S1). High expression levels were observed in the different parts of the brain. Abundant expression of APCN message was also seen in fetal tissues, especially in the brain, heart, and kidney (Supplemental Figure S3B).

To localize the tissue distribution of APCN protein expression, an antibody was raised in rabbits to a synthetic peptide representing amino acids 378 to 394 (called MAP346). The specificity of MAP346 was validated by double immunofluorescence (Supplemental Figure S2, $\mathrm{G}-\mathrm{I})$. Because brain tissue showed strong signals in Northern blot analysis, sections from normal human brain were stained by immunohistochemistry. An intense reticular staining was seen in glia limitans in a distribution corresponding to the abundant astrocyte processes and in pyramidal neurons (Figure 3A). Because of the robust appearance of the protein in astrocytes (Figure 3B), the protein was called astroprincin.
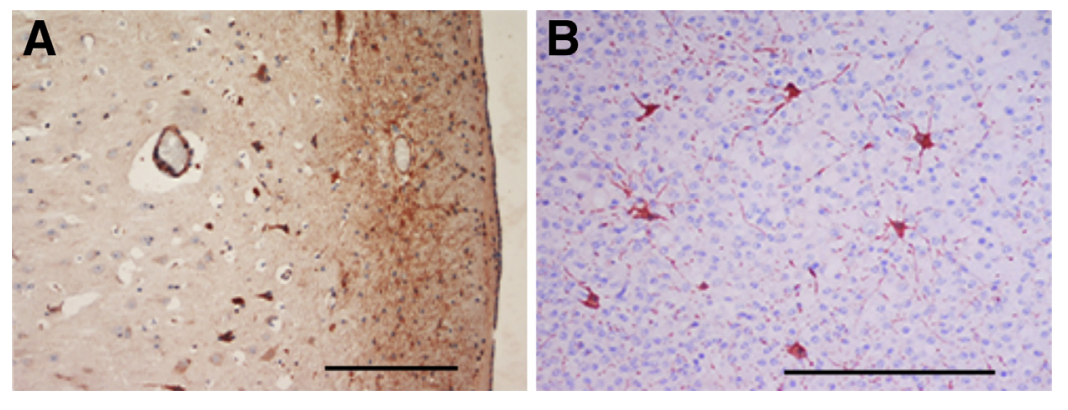

Figure 3 Immunohistochemistry showing APCN expression in glia limitans of human brain and in pyramidal neurons (A) and astrocytes (B). Scale bars: $100 \mu \mathrm{m}$ (A); $20 \mu \mathrm{m}$ (B). 

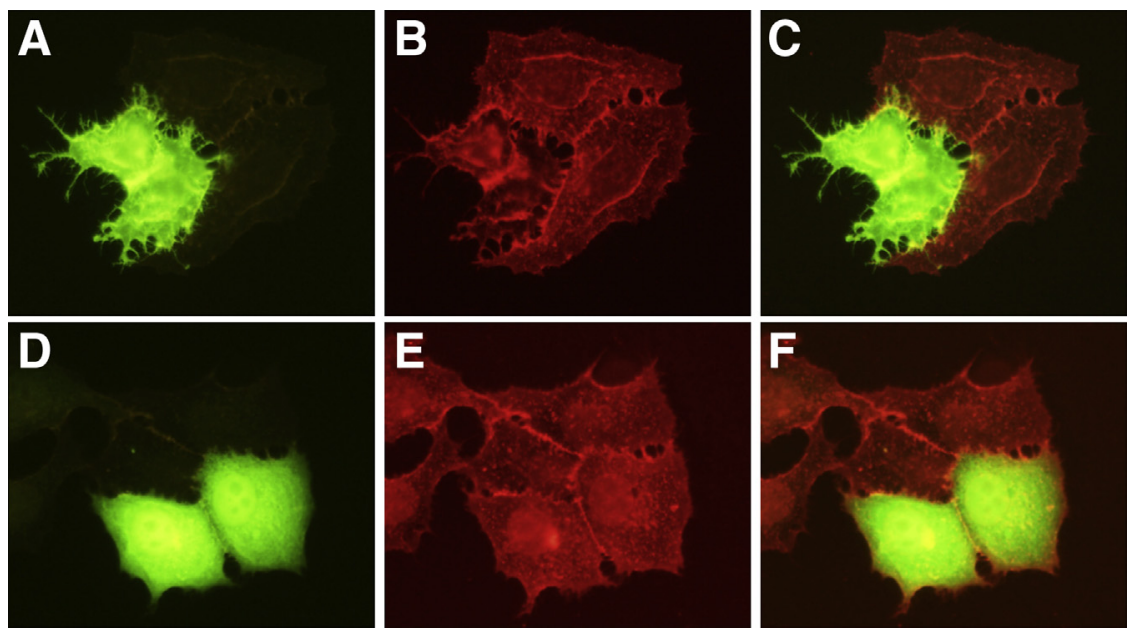

Figure 4 A and D: Impact of APCN on cell shape. Expression of (CDNA)flAPCN-Flag in MCF-7 cells induces membrane sprouting (A) not seen with cytAPCN-Flag (Supplemental Figure S1) (D), as visualized with mouse monoclonal antibody to Flag and goat anti-mouse-fluorescein isothiocyanate antibodies. B and E: The cell membranes are visualized with wheat germ agglutinin-TRITC (B and E). C and F: Merged images. Original magnification, $\times 400(\mathbf{A}-\mathbf{F})$

\section{Transfection of APCN CDNA Changes Cell Shape}

Transient transfection with (cDNA) flAPCN-FLAG induced dramatic changes in the cell shape. Overexpressed APCN induced sprouting of slender, dendrite-like and branching projections. This effect was consistently seen in all cells tested (MCF-7, HEK293, COS-7, NIH3T3, and SK-MEL28). MCF-7 cells are shown in Figure 4, A-C.

To investigate which part(s) of APCN is needed to induce sprouting of dendrites, a panel of truncated, C-terminally FLAG-tagged cDNA constructs was made (Supplemental Figure S1) and transfected into cells. The integrity of the different C-terminally FLAG-tagged truncation clones was affirmed by sequencing.

When MCF-7 cells were transfected with a FLAG-tagged intracytoplasmic portion of (cDNA)APCN with deleted extracellular and the transmembrane parts, no sprouting was induced. The cells retained the shape of untransfected cells, with cytoplasmic accumulation of the truncated protein (Figure 4, D-F).

\section{Down-Regulation of Endogenous APCN Expression by siRNA Inhibits Actin Stress Fiber Formation}

To investigate the functional interaction between APCN and the actin cytoskeleton, SK-MEL-147 cells grown on coverslips were transfected with 6-carboxyfluorescein-labeled siRNA to $A P C N$ or with control siRNA. Staining of the cells after 72 hours with TRITC-phalloidin showed that expression of APCN siRNA induced redistribution of the cytoskeletal actin with disappearance of stress fibers (Figure 5, A-C), whereas cells transfected with control siRNA displayed well-organized
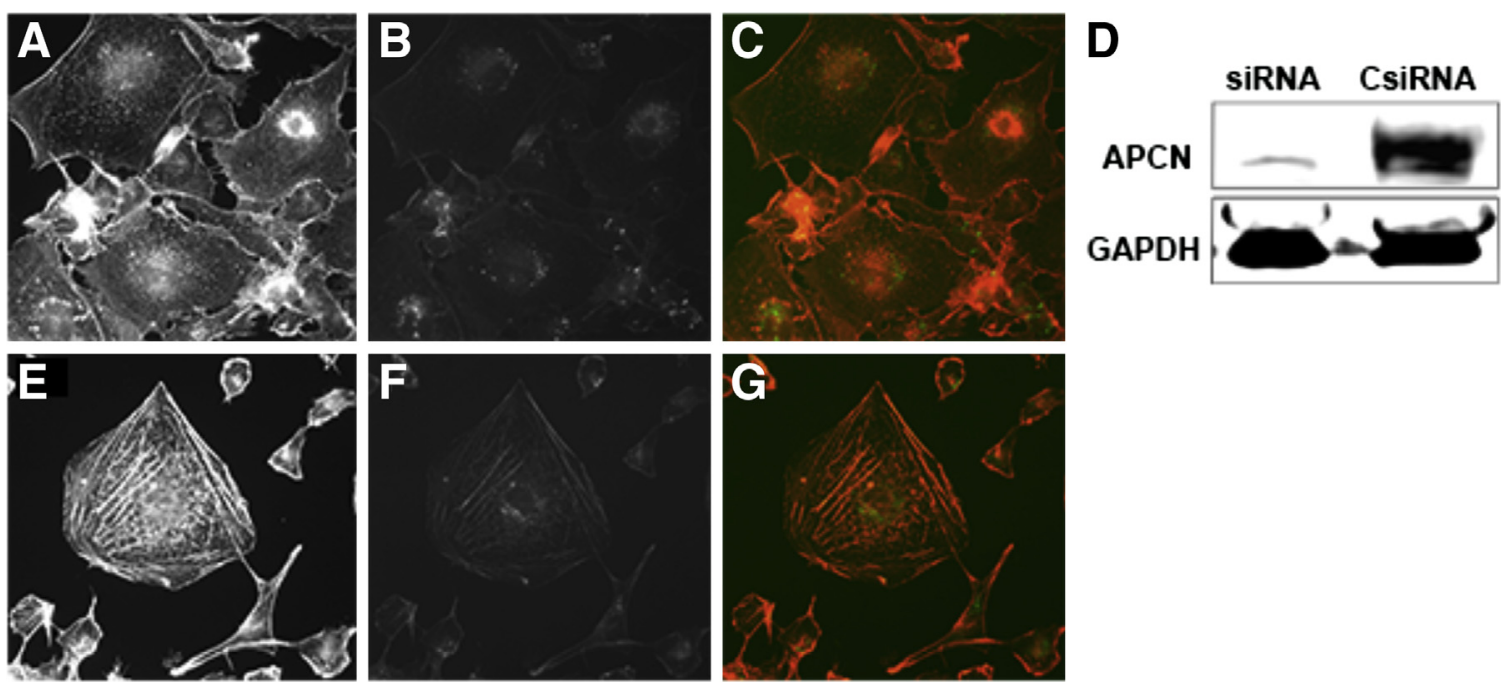

Figure 5 A: Transfection of SK-MEL-147 cells with APCN siRNA induces loss of stress fibers. B and F: Visualization of 6-carboxyfluorescein-labeled siRNAs. C and G: Merged images. D: Western blot analysis showing the efficiency of siRNA-mediated down-regulation of APCN expression (siRNA) compared with control siRNA (CsiRNA). E: Cells transfected with control siRNA display robust stress fibers. Original magnification, $\times 630$ (A-C and E-G). GAPDH, glyceraldehyde-3-phosphate dehydrogenase. 

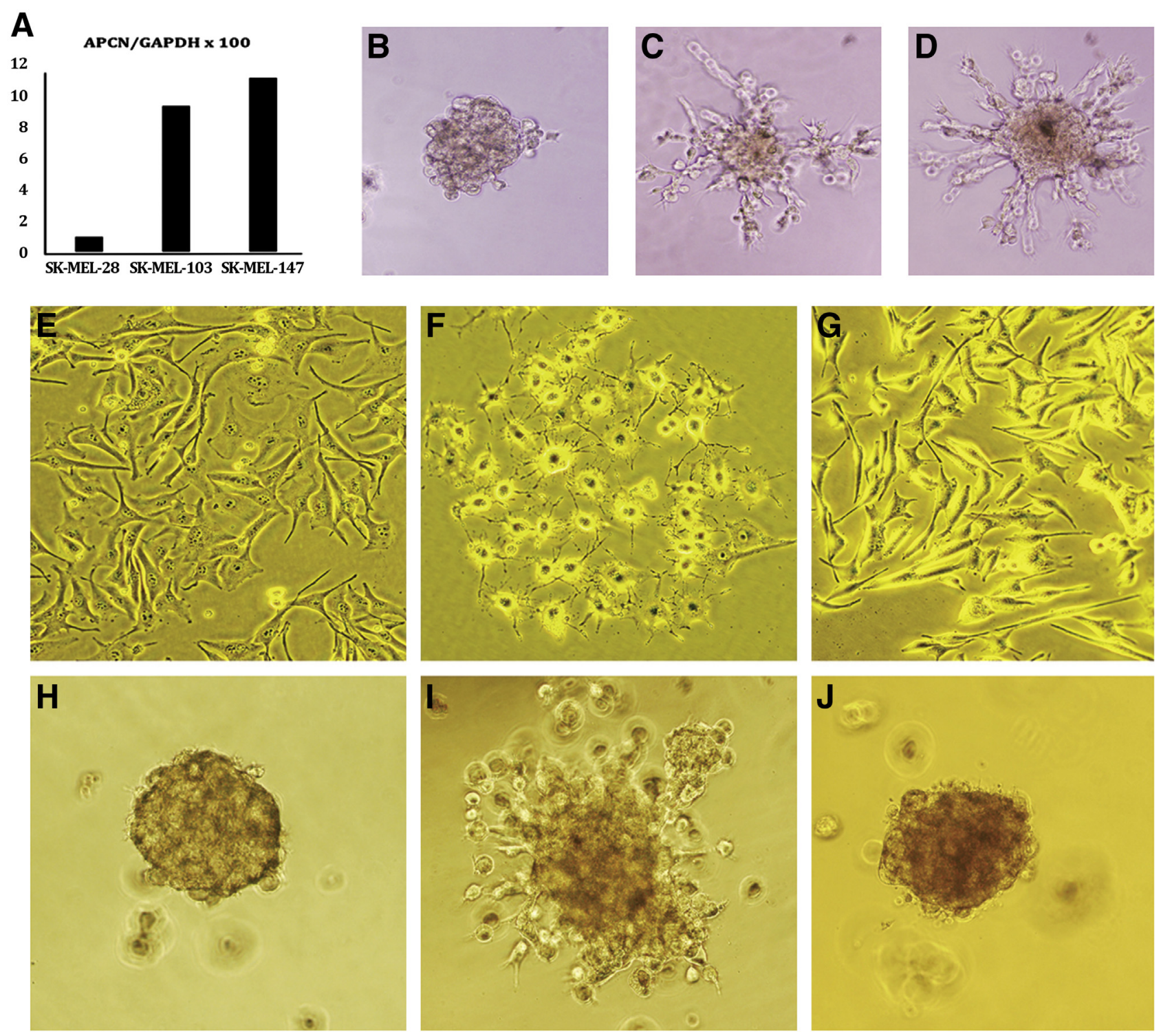

Figure 6 A: Relative expression levels of endogenous APCN mRNA, measured by real-time quantitative PCR in the melanoma cell lines SK-MEL-28, SK-MEL103, and SK-MEL-147. B-D: SK-MEL-28 does not invade Matrigel (B), like SK-MEL-103 (C) and SK-MEL-147 (D) cells. E-J: Transfection of SK-MEL-28 cells with the empty vector (control; $\mathbf{E}$ and $\mathbf{H}$ ), with (CDNA)fLAPCN (F and $\mathbf{I}$ ), or with (CDNA)APCN lacking the 21 -terminal amino acids ( $\mathbf{G}$ and $\mathbf{J})$ showed that APCN induced sprouting (F) and ability to invade Matrigel (I) and that the C-terminal 21 amino acids are needed for the APCN activity (G and $\mathbf{J})$. Original magnification: $\times 100(\mathbf{B}-\mathbf{D}$ and $\mathbf{H}-\mathbf{J}) ; \times 200(\mathbf{E}-\mathbf{G})$. GAPDH, glyceraldehyde-3-phosphate dehydrogenase.

stress fibers (Figure 5, D-G). APCN siRNA transfection of U393MG astrocytoma cells also induced disappearance of stress fibers and accumulation of actin in donut-like protrusions at the cell edges (Supplemental Figure S4).

\section{The Conserved Carboxyterminal 21 Amino Acids of APCN Are Needed for Cell Sprouting and Invasive Growth}

Analysis by real-time quantitative PCR and Western blot analysis of human melanoma cell lines revealed higher expression of endogenous APCN transcript and protein in SK-MEL-103 and in SK-MEL-147 than in SK-MEL-28 melanoma cells (Figure 6A). SK-MEL-28 cells did not invade Matrigel (Figure 6B), whereas SK-MEL-103 (Figure 6C) and SK-Mel-147 (Figure 6D) cells displayed invasive growth in Matrigel. Overexpression of fulllength (cDNA)APCN in SK-MEL-28 cells induced sprouting of slender projections and ability to grow invasively in Matrigel (Figure 6, F and I), not seen with SK-MEL-28 cells transfected with the empty vector (Figure 6, E and $\mathrm{H}$ ).

To investigate which part(s) of the APCN molecule was of importance for induction of invasive cell growth, mutated constructs of (cDNA)APCN were expressed in SK-MEL-28 cells. Expression of (cDNA)T3-APCN (Supplemental Figure S1) with deletion of the ultimate 21 carboxyterminal amino acids (869 to 890 ) in SK-MEL-28 cells did 


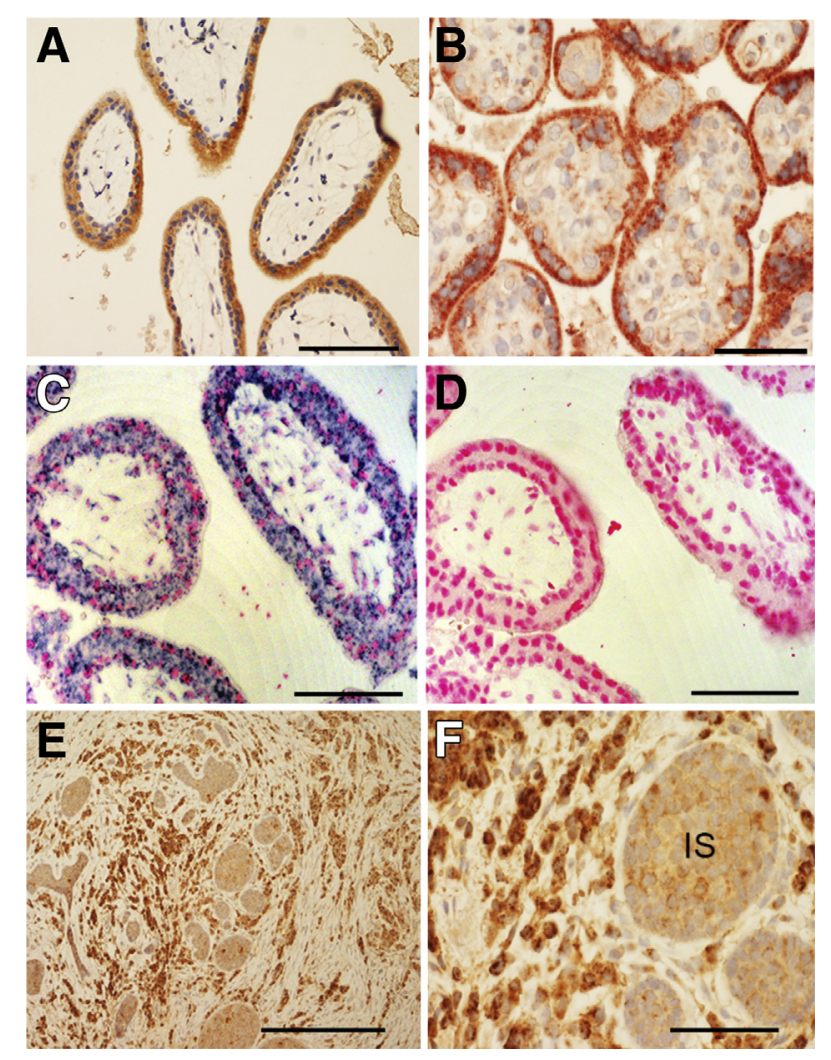

Figure 7 Immunohistochemical (IHC) staining with MAP346 antibodies shows trophoblastic expression of APCN in early (A) and full-term (B) placentas. In situ hybridization with $A P C N$ complementary RNA anti-sense (C) and sense (D) probes, showing APCN mRNA in trophoblasts of early placenta. IHC with MAP346 of sections from lobular breast cancer (E and $\mathbf{F}$ ) shows elevated expression of APCN in infiltrating cancer cells compared with cells in the in situ (IS) lesions. Scale bars: $100 \mu \mathrm{m}$ (A and B); $50 \mu \mathrm{m}$ (C, D, and F); $200 \mu \mathrm{m}$ (E).

not induce sprouting in monolayer cultures or invasive growth in Matrigel (Figure 6, G and J).

\section{High Expression of Endogenous APCN in Placental Trophoblasts and Invasive Cancer}

Because trophoblasts are physiologically invasively growing cells, immunohistochemical staining was performed with MAP346 of early (H5) and full-term placenta. The results showed robust trophoblast expression of APCN (Figure 7, A and B). In situ hybridization with antisense and sense RNA probes to $A P C N$ revealed presence of $A P C N$ mRNA in the trophoblast layers of early placenta (Figure 7, $\mathrm{C}$ and D).

Immunohistochemistry with MAP346 also discerned enhanced expression of APCN at the invasive front of nodular melanomas and in particular in individual infiltrating tumor cells (data not shown). In sections of lobular breast cancer containing both noninvasive, in situ lesions and infiltrating tumor cells, a robustly up-regulated expression of APCN was found in the invasively growing cancer cells. Normal lobular epithelium remained negative for APCN (Figure 7, E and F).
Colocalization of APCN with Integrin $\beta 1$ and ADAM10 in U373MG Astrocytoma Cells

Confocal microscopy of immunofluorescence costaining of U373MG cells, transiently transfected with (cDNA)APCN with rabbit antibodies to APCN and mouse monoclonal antibodies to endogenous $\beta 1$ integrin, revealed an overlapping distribution (Figure 8, A-C). Costaining of U373 cells with antibodies to ADAM10 and MAP346 to endogenous APCN revealed codistribution at the leading edge of the cells (Figure 8, D-F).

APCN Interacts with ADAM10, Ornithine Decarboxylase Antizyme-1, and NEEP21 (NSG1)

Yeast two-hybrid screening revealed several putative binding partners of APCN, among which ADAM10, ornithine decarboxylase AZ-1, and NEEP21 (NSG1) were selected for initial validation.

Immunoprecipitation with antibodies to ADAM10 from lysates of COS-7 cells cotransfected with (cDNA)ADAM10$M y c$ and (cDNA)APCN-FLAG pulled down APCN (Figure 9A), confirming the interaction between APCN and ADAM10.

Binding of AZ-1 to APCN was studied by coexpression of (cDNA)AZ-1 with a 5 'myc tag and FLAG-tagged (cDNA)flAPCN in COS-7 cells. Immunoprecipitation from lysates of transfected cells with anti-FLAG, followed by Western blot analysis with antibodies to AZ-1 showed coprecipitation of AZ-1 (Figure 9B). APCN with deletion of the conserved portion between amino acids 541 and 746 $(\triangle 3-A P C N)$ (Supplemental Figure S1) did not pull down AZ-1 (Supplemental Figure S5).

Immunoprecipitation of lysates from COS-7 cells cotransfected with NEEP21-Myc and APCN-Flag cDNA constructs with antibodies to APCN also brought down NEEP21, indicating formation of detergent-resistant protein complexes (Figure 9C).

\section{Discussion}

In this article, we report the first functional characterization of the APCN protein. Human APCN (alias FAM171A1 or C10orf38) is a type I transmembrane glycoprotein and a member of the UPF0560 protein family that also includes FAM171A2, encoded by a gene on chromosome 17q21.31, and FAM171B on chromosome 2q32.1. FAM171A2 shows $39 \%$ and FAM171B shows $32 \%$ identity with APCN. The $A P C N$ gene is located on chromosome $10 \mathrm{p} 13$, a region that is deleted in DiGeorge type 2 and velocardiofacial syndromes. ${ }^{18}$

Hybridization experiments and immunohistochemistry revealed physiological expression of APCN in various tissues, particularly in the brain, where the astrocytes exhibit abundant APCN. 

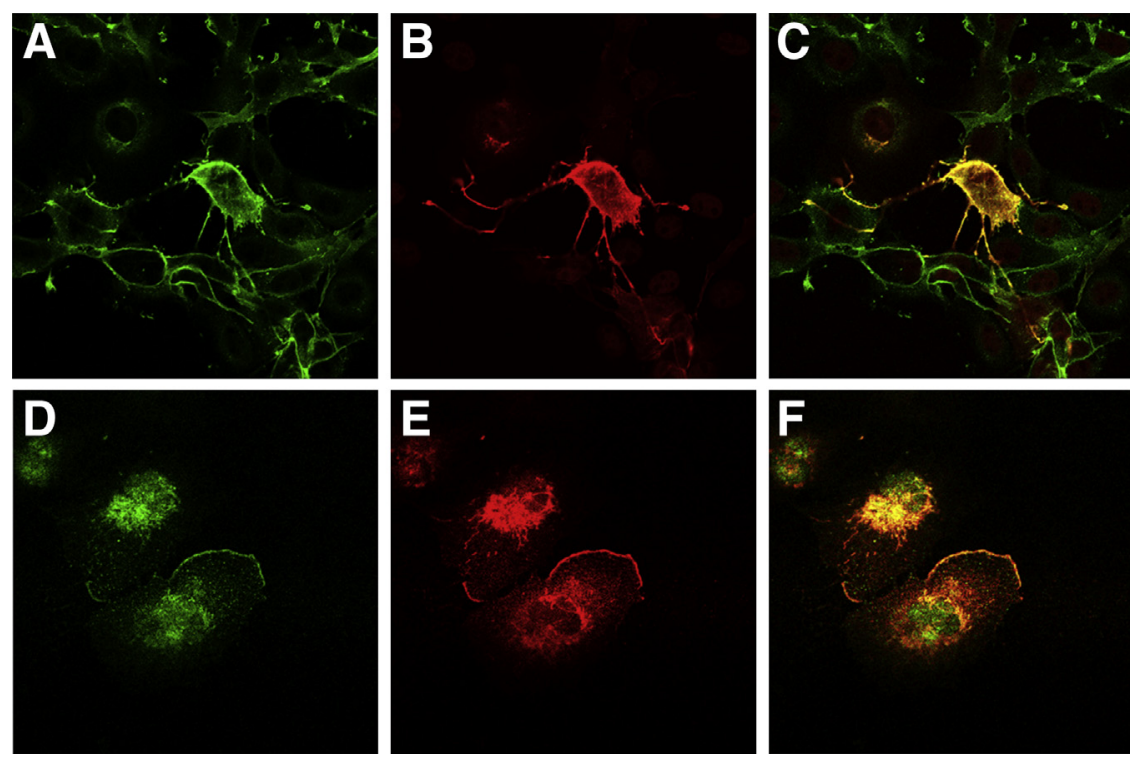

Figure 8 A and B: Confocal microscopy of U373MG cells transiently transfected with (cDNA) APCN-Flag and costained with monoclonal antibodies to human $\beta 1$-integrin (A) and with antiFLAG (B). C: Merged image. D and E: Staining of U373MG astrocytoma cells with antibodies to ADAM10 (D) and with MAP346 to endogenous APCN (E). F: Merged image. Original magnification: $\times 400(\mathbf{A}-\mathbf{C}) ; \times 630(\mathbf{D}-\mathbf{F})$.
Yeast two-hybrid screening indicated ornithine decarboxylase (ODC) AZ-1 binding to APCN. This was validated by coimmunoprecipitation, and the binding site was localized to a domain between amino acids 541 and 746, including the region between amino acids 541 and 569 that is highly conserved in the three members of the FAM171 proteins and in Fam171a1 proteins of different species. The activity of ODC, the rate-limiting enzyme of polyamine synthesis, is intimately coupled to cell activation, transformation, and proliferation. ${ }^{19}$

ODC translocates to the plasma membrane during cell activation. ${ }^{20}$ ODC activity is required for microvascular sprouting and remodeling of the actin cytoskeleton in endothelial cells. ${ }^{21}$ Moreover, ODC activity or local polyamine synthesis regulates the activity and traffic of RhoA, which is a main regulator of the dynamics of the actin cytoskeleton. ${ }^{22}$ A sizeable portion of cellular ODC is sequestered in catalytically inactive form to AZ-1 and gets released and activated by competitive binding of antizyme inhibitor. The interaction between AZ-1 and APCN may provide a mechanism by which ODC is targeted to the membrane, where the activity is of importance for cytoskeletal reorganization occurring during formation of cellular sprouts and acquisition of invasive phenotype.

Overexpression of full-length (cDNA)APCN induced outgrowth of slender and frequently branched extensions in both epithelial and mesenchymal cell lines. This was not seen with (cDNA)APCN lacking the extracellular portion. These finding suggested the APCN is involved in signaling between the cytoskeleton and the external environment.

A role for APCN in the maintenance of an organized actin cytoskeleton is further supported by these findings, showing that down-regulation of endogenous $A P C N$ by siRNA interference provoked disappearance of organized actin
A

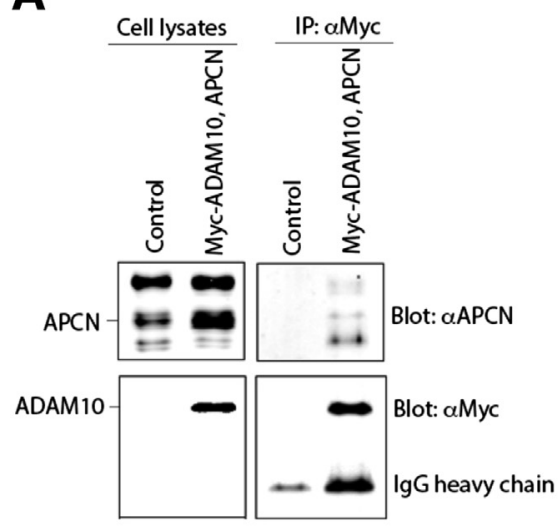

B

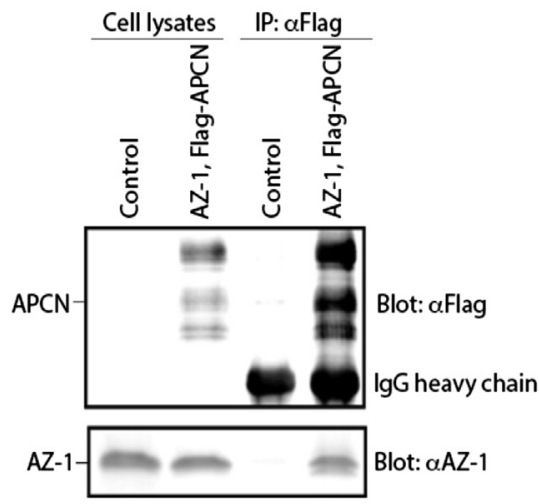

C

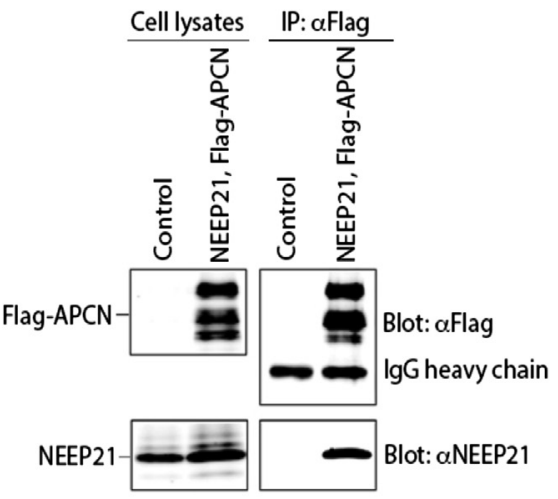

Figure 9 Interaction of APCN with ADAM10 (A), antizyme-1 (AZ-1; B), and NEEP21 (NSG1) (C), shown by coimmunoprecipitation and Western blot analysis of lysates from COS-7 cells transiently cotransfected with (CDNA)ADAM10 and (CDNA)flAPCN-Flag (A), (cDNA) AZ-1 with a $5^{\prime}$ myc tag and (cDNA) flAPCN-Flag (B), and (CDNA) NEEP21-Flag and (CDNA)fLAPCN (C). IP, immunoprecipitation. 
stress fibers. Our attempts to delete endogenous $A P C N$ expression by clustered regularly interspaced short palindromic repeats (CRISPR)/Cas9 technology failed because viable cells could not be selected with total knockout of both alleles. Occasional polykaryotic cells with $>20$ nuclei per cell were found (data not shown). This suggests that total absence of endogenous $A P C N$ causes disturbance in the actin dynamics needed for cytokinesis.

APCN is not known to mediate cell adhesion, but by confocal microscopy, a colocalization with integrin $\beta 1$ was observed. Whether there is a direct interaction between integrin $\beta 1$ and APCN or whether the observed colocalization is attributable to formation of a larger complex with other proteins remains to be investigated.

ADAM10, like APCN, is a transmembrane type I glycoprotein with a complex $\mathrm{N}$-glycoside side chain. The short intracytoplasmic portion contains two SH3 motifs and a consensus binding site for calmodulin. It is a member of transmembrane zinc-dependent metalloproteinase or sheddase acting as amyloid precursor protein, cleaving $\alpha$ secretase. More than 20 membrane-bound proteins have been identified as ADAM10 substrates, including Notch, pro-epidermal growth factor, ErbB2, E-cadherin, CD44, and inflammatory cytokines. ${ }^{23}$ ADAM10 is also essential for migration of neuronal precursors during embryonic brain morphogenesis. ${ }^{24}$ Double immunofluorescence showed colocalization of endogenous ADAM10 and APCN in the leading edge of U373MG astrocytoma cells. It is tempting to speculate that interaction between ADAM10 and APCN is of relevance for brain morphogenesis and in particular for the arborization of astrocytes. Elevated expression of ADAM10 has also been reported to enhance growth and metastatic dissemination of neoplasms, including melanomas, breast cancer, and liver cancers. ${ }^{25,26}$ Release of NLGN3, which promotes glioma growth and differentiation, was recently shown to be mediated by ADAM10. ${ }^{27}$

There is limited information in the literature about a neuron-enriched endosomal protein of $21 \mathrm{kDa}$, NSG1 (NEEP21). NEEP21 has been found functionally involved in regulation of endosomal vesicle trafficking and membrane receptor recycling. ${ }^{28}$ NEEP21 is involved in sorting of the neuron-glial adhesion molecule $\mathrm{L} 1 / \mathrm{NgCAM}$ that regulates outgrowth of neurites. ${ }^{29}$ Elevated expression of $\mathrm{L} 1 / \mathrm{NgCAM}$, on the other hand, has been found in a variety of cancers, where it correlates with aggressive behavior of the neoplasm. ${ }^{30}$

By expression of deletion mutants of $A P C N$ cDNA, it was found that the $21 \mathrm{C}$-terminal amino acids are required for induction of invasive growth and sprouting of SK-MEL-28 melanoma cells. This sequence is also present in the two other members of the FAM171 protein family and is conserved in APCN of different species. A motif search revealed domains of homology in MAP1A, a structural protein that is involved in cross-bridging between microtubules and other cytoskeletal elements. ${ }^{31,32}$ These include Ephexin-2, which is a guanine nucleotide exchange factor for RhoA GTPase; and pleckstrin homology domaininteracting protein, which is involved in regulation of cell morphology and cytoskeletal organization. ${ }^{33,34}$ Moreover, BCAS1, which is amplified in a variety of cancers and associates with more aggressive tumor types, also carries a homologous motif. We are presently investigating the molecular details of the interactions of the N-terminal domain of APCN.

BLAST searches of the conserved extracellular regions of APCN revealed a neural cell adhesion moleculehomologous motif in the domain between amino acids 85 and 113. NCAM mediates neuron-neuron adhesion and is involved in neurite outgrowths. A region present in APCN 137 to 160 is also found in Septin5, which is encoded by a gene located on $22 \mathrm{q} 11.2$, a chromosomal region that is deleted in diseases, including DiGeorge and velocardiofacial syndromes. ${ }^{18}$

Taken together, we report the first functional characterization of APCN. Further investigations are required to unravel the molecular details of APCN, but the emerging picture is an evolutionarily highly conserved type I transmembrane glycoprotein that is involved in the regulation of the cytoskeletal dynamics and, thereby, the cell shape and invasive growth behavior of tumor cells.

\section{Acknowledgments}

We thank Tiiu Arumäe for technical help, Prof. Bengt Westermark (University of Uppsala) for providing the U373MG astrocytoma line, Dr. Maria Soengas (Spanish National Cancer Research Center) for providing SK-MEL103 and SK-MEL-147 (both originating from Dr. Alan Houghton, Memorial Sloan-Kettering Cancer Center), Dr. Tomi Mäkelä (University of Helsinki) for proving pCI-Neo containing N-terminal c-Myc, Prof. Shin-ichi Hayashi (Jikei University School of Medicine) for providing antizyme-1 cDNA, and Dr. Rik Derynck (University of California, San Francisco) for providing the Myc-ADAMIO expression construct (Addgene plasmid number 31717).

\section{Supplemental Data}

Supplemental material for this article can be found at https://doi.org/10.1016/j.ajpath.2018.09.006.

\section{References}

1. Deloukas P, Earthrowl ME, Grafham DV, Rubenfield M, French L, Steward CA, et al: The DNA sequence and comparative analysis of human chromosome 10. Nature 2004, 429:375-381

2. Simmen FA, Su Y, Xiao R, Zeng Z, Simmen RC: The Kruppel-like factor 9 (KLF9) network in HEC-1-A endometrial carcinoma cells suggests the carcinogenic potential of dys-regulated KLF9 expression. Reprod Biol Endocrinol 2008, 6:41 
3. Liao Y, Pei J, Cheng H, Grishin NV: An ancient autoproteolytic domain found in GAIN, ZU5 and nucleoporin98. J Mol Biol 2014, 426:3935-3945

4. Ipsaro JJ, Huang L, Gutierrez L, MacDonald RI: Molecular epitopes of the ankyrin-spectrin interaction. Biochemistry 2008, 47:7452-7464

5. Prunotto M, Farina A, Lane L, Pernin A, Schifferli J, Hochstrasser DF, Lescuyer P, Moll S: Proteomic analysis of podocyte exosome-enriched fraction from normal human urine. J Proteomics 2013, 82:193-229

6. Emdal KB, Pedersen AK, Bekker-Jensen DB, Tsafou KP, Horn H, Lindner S, Schulte JH, Eggert A, Jensen LJ, Francavilla C, Olsen JV: Temporal proteomics of NGF-TrkA signaling identifies an inhibitory role for the E3 ligase Cbl-b in neuroblastoma cell differentiation. Sci Signal 2015, 8:ra40

7. St-Denis N, Gupta GD, Lin ZY, Gonzalez-Badillo B, Veri AO, Knight JDR, Rajendran D, Couzens AL, Currie KW, Tkach JM, Cheung SWT, Pelletier L, Gingras AC: Phenotypic and interaction profiling of the human phosphatases identifies diverse mitotic regulators. Cell Rep 2016, 17:2488-2501

8. Huttlin EL, Bruckner RJ, Paulo JA, Cannon JR, Ting L, Baltier K, Colby G, Gebreab F, Gygi MP, Parzen H, Szpyt J, Tam S, Zarraga G, Pontano-Vaites L, Swarup S, White AE, Schweppe DK, Rad R, Erickson BK, Obar RA, Guruharsha KG, Li K, ArtavanisTsakonas S, Gygi SP, Harper JW: Architecture of the human interactome defines protein communities and disease networks. Nature 2017, 545:505-509

9. Gayet O, Labella V, Henderson CE, Kallenbach S: The b1 isoform of protocadherin-gamma (Pcdhgamma) interacts with the microtubuledestabilizing protein SCG10. FEBS Lett 2004, 578:175-179

10. Haltaufderhyde KD, Oancea E: Genome-wide transcriptome analysis of human epidermal melanocytes. Genomics 2014, 104:482-489

11. Santuario-Facio SK, Cardona-Huerta S, Perez-Paramo YX, Trevino V, Hernandez-Cabrera F, Rojas-Martinez A, UscangaPerales G, Martinez-Rodriguez JL, Martinez-Jacobo L, PadillaRivas G, Munoz-Maldonado G, Gonzalez-Guerrero JF, ValeroGomez J, Vazquez-Guerrero AL, Martinez-Rodriguez HG, BarbozaQuintana A, Barboza-Quintana O, Garza-Guajardo R, OrtizLopez R: A new gene expression signature for triple negative breast cancer using frozen fresh tissue before neoadjuvant chemotherapy. Mol Med 2017, 23:101-111

12. Pitkänen LT, Heiskala M, Andersson LC: Expression of a novel human ornithine decarboxylase-like protein in the central nervous system and testes. Biochem Biophys Res Commun 2001, 287: $1051-1057$

13. Sambrook J, Russell DW: Molecular Cloning: A Laboratory Manual. Cold Spring Harbor. NY, Cold Spring Harbor Laboratory Press, 2001

14. Lee J, Lee HJ, Shin MK, Ryu WS: Versatile PCR-mediated insertion or deletion mutagenesis. Biotechniques 2004, 36:398-400

15. Edelheit O, Hanukoglu A, Hanukoglu I: Simple and efficient sitedirected mutagenesis using two single-primer reactions in parallel to generate mutants for protein structure-function studies. BMC Biotechnol 2009, 9:61

16. Tiainen M, Ylikorkala A, Mäkelä TP: Growth suppression by Lkb1 is mediated by a G(1) cell cycle arrest. Proc Natl Acad Sci U S A 1999, 96:9248-9251

17. Liu C, Xu P, Lamouille S, Xu J, Derynck R: TACE-mediated ectodomain shedding of the type I TGF-beta receptor downregulates TGFbeta signaling. Mol Cell 2009, 35:26-36
18. Daw SC, Taylor C, Kraman M, Call K, Mao J, Schuffenhauer S, Meitinger T, Lipson T, Goodship J, Scambler P: A common region of $10 \mathrm{p}$ deleted in DiGeorge and velocardiofacial syndromes. Nat Genet 1996, 13:458-460

19. Kahana C: Regulation of cellular polyamine levels and cellular proliferation by antizyme and antizyme inhibitor. Essays Biochem 2009, 46:47-61

20. Heiskala M, Zhang J, Hayashi S, Hölttä E, Andersson LC: Translocation of ornithine decarboxylase to the surface membrane during cell activation and transformation. EMBO J 1999, 18:1214-1222

21. Kucharzewska P, Welch JE, Svensson KJ, Belting M: Ornithine decarboxylase and extracellular polyamines regulate microvascular sprouting and actin cytoskeleton dynamics in endothelial cells. Exp Cell Res 2010, 316:2683-2691

22. Mäkitie LT, Kanerva K, Andersson LC: Ornithine decarboxylase regulates the activity and localization of rhoA via polyamination. Exp Cell Res 2009, 315:1008-1014

23. White JM: ADAMs: modulators of cell-cell and cell-matrix interactions. Curr Opin Cell Biol 2003, 15:598-606

24. Jorissen E, Prox J, Bernreuther C, Weber S, Schwanbeck R, Serneels L, Snellinx A, Craessaerts K, Thathiah A, Tesseur I, Bartsch U, Weskamp G, Blobel CP, Glatzel M, De Strooper B, Saftig P: The disintegrin/metalloproteinase ADAM10 is essential for the establishment of the brain cortex. J Neurosci 2010, 30: $4833-4844$

25. Mochizuki S, Okada Y: ADAMs in cancer cell proliferation and progression. Cancer Sci 2007, 98:621-628

26. Murphy G: The ADAMs: signalling scissors in the tumour microenvironment. Nat Rev Cancer 2008, 8:929-941

27. Venkatesh HS, Tam LT, Woo PJ, Lennon J, Nagaraja S, Gillespie SM, Ni J, Duveau DY, Morris PJ, Zhao JJ, Thomas CJ, Monje M: Targeting neuronal activity-regulated neuroligin-3 dependency in highgrade glioma. Nature 2017, 549:533-537

28. Muthusamy N, Chen YJ, Yin DM, Mei L, Bergson C: Complementary roles of the neuron-enriched endosomal proteins NEEP21 and calcyon in neuronal vesicle trafficking. J Neurochem 2015, 132:20-31

29. Yap CC, Wisco D, Kujala P, Lasiecka ZM, Cannon JT, Chang MC, Hirling H, Klumperman J, Winckler B: The somatodendritic endosomal regulator NEEP21 facilitates axonal targeting of L1/NgCAM. J Cell Biol 2008, 180:827-842

30. Altevogt P, Doberstein K, Fogel M: L1CAM in human cancer. Int J Cancer 2016, 138:1565-1576

31. Fink JK, Jones SM, Esposito C, Wilkowski J: Human microtubuleassociated protein 1a (MAP1A) gene: genomic organization, cDNA sequence, and developmental- and tissue-specific expression. Genomics 1996, 35:577-585

32. Halpain S, Dehmelt L: The MAP1 family of microtubule-associated proteins. Genome Biol 2006, 7:224

33. Lajoie-Mazenc I, Tovar D, Penary M, Lortal B, Allart S, Favard C, Brihoum M, Pradines A, Favre G: MAP1A light chain-2 interacts with GTP-RhoB to control epidermal growth factor (EGF)-dependent EGF receptor signaling. J Biol Chem 2008, 283:4155-4164

34. Fuhrmann-Stroissnigg H, Noiges R, Descovich L, Fischer I, Albrecht DE, Nothias F, Froehner SC, Propst F: The light chains of microtubule-associated proteins MAP1A and MAP1B interact with alpha1-syntrophin in the central and peripheral nervous system. PLoS One 2012, 7:e49722 